\title{
Cognitive Behavioral Counseling with Modelling Pan Balang Tamak to Improve Persuasive
}

\author{
Komang Adi Cipta Ananda ${ }^{1}$, I Ketut Dharsana ${ }^{2}$, Ni Ketut Suarni ${ }^{3}$ \\ ${ }^{123}$ Universitas Pendidikan Ganesha \\ e-mail: ciptaananda@gmail.com
}

Received July 07,2017

Revised August 14, 2017

Accepted October 23, 2017

Published Online December 30, 2017

\section{Conflict of Interest Disclosures:}

The authors declare that they have no significant competing financial, professional or personal interests that might have influenced the performance or presentation of the work described in this manuscript.

\begin{abstract}
This study aimed to determine the effect of cognitive behavioral counseling by modeling techniques Pan balang greedy to increased interest persuasive students through lesson study VIII.4 grade students of SMP Negeri 2 Singaraja. This research is the study design "quasi-experimental (Quasi Experiment)" Design nonequivalent pretest-posttest control group design. The sampling technique used is random sampling and random class as an intact group of subjects of this study were 38 people VIII.4 grade students of SMP Negeri 2 Singaraja. The process of taking data in this study using the method of observation, interviews, diaries and questionnaires Interests linkert scale pattern persuasive and descriptive analysis and statistical analysis used the formula for the t-test. Empirical findings in this study stated that there are significant cognitive-behavioral counseling by modeling techniques Pan balang greedy to increased interest persuasive students through lesson study VIII.4 grade students of SMP Negeri 2 Singaraja. This is evidenced by the $t$ value of 3,516 sig.0,01 with 0:01 $<0.05$. with a significance level (p) $<0.05$ indicating that counseling services will be more effective if counselees in the implementation of the service is facilitated by modeling techniques Balang Greed Pan models. Based on this statement we can say that the cognitivebehavioral counseling by modeling techniques Balang Greed Pan right models applied in schools.
\end{abstract}

Keywords: cognitive-behavioral counseling, modeling pan balang greedy, interest persuasive

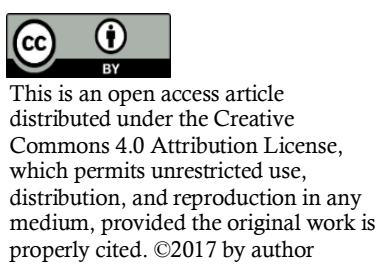

How to Cite: Ananda, K. A. C., Dharsana, I. K., \& Suarni, N. K. (2017). Cognitive Behavioral Counseling with Modelling Pan Balang Tamak to Improve Persuasive. Bisma, 1(2), 60-68. https://doi.org/10.23887/128162017

\section{Introduction}

Based on the observations of investigators at the time of execution of PPL Real and practice internship counseling / field practice counseling in schools (PLBKS) in the class of grade VIII SMP Negeri 2 Singaraja, of 37 student researchers looked at 17 students showed symptoms such as demonstrating the attitudes of students looking very once difficult and very reluctant to approach, difficult to influence people, and hard to convince people, researchers found 20 other students had symptoms like that is easy to approach, easy to influence people, and is easy to convince people. Symptoms such students can be said to exhibit symptoms of "interest persuasive. 


\section{Interests Persuasive}

According Dharsana (2013: 2) "Interest persuasive that the interest of a person to approach, the interest to influence people, and interests to convince people. Based definisitersebut, then the "interest persuasive" in that it contains three aspects: 1) the interests of a person to approach, 2) interest to influence people, and 3) interest to convince people.

Another suggestion is (Ajzen, 1971; D'Hondt \& VSNU, 2006; Dharsana, 2017; Greenwald, 1968; Moyer-Guse, 2008; Olson \& Zanna, 1993; Rokhimah 2011; Simorangkir et al., 2014; Sinaga, 2014; Wood, 2000)Interests persuasive, namely interest-related work affects others ". Based on these definitions, the "interest persuasive" in that it contains one aspect, namely: (1) influencing others.

In Big Indonesian Dictionary persuasive is the interest that is of interest means the tendency of elevated liver against something, while persuasive is subtly persuasive in order to be sure. So we can conclude persuasive interest is high liver tendency to subtly persuade others to become convinced.

Based on the definition of exposure, so in this study is the "interest persuasive" is a person's interest to approach people, interests to influence, and interests to convince people. Based on these definitions, the "interest persuasive" in that it contains three aspects: 1) the interests of a person to approach, 2) interest to influence people, and 3) interest to convince people.

Persuasive in increasing interest of students, there are various attempts to do, namely: the educational efforts, with training efforts, the efforts of psychological treatments and counseling efforts. Educational efforts are only one way that does not cause intraksi that the inter-individual to another, if the training implementation shorter so it can not focus, whereas when using treatments psychology requires scientific in and when using the efforts of the counseling, the researchers already have a background in expertise counseling obtained from the first semester to semester VII. In connection with that, the researchers chose to raise Self Achievement using guidance and counseling approach.

\section{Cognitive Behavioral Counseling}

According Dharsana (2016: 98) Counseling cognitive-behavioral Aaron T Back has five categories of schemes, namely (1) Cognitive (working unreal / invisible, interpreting call back and evacuating people and others), (2) Affective (responsible for generating feelings), (3) Motivation (concerns relating to expectations and beliefs, (4) Instrumental (preparing people to react, and (5) Controls (involving monitor themselves and prohibitions, change and deeds langung or indirect (Armasari, Dantes, and Sulastri, 2013; Padmi, 2017; Rabiatul, 2017; Sanyata, 2012; Saraswati, Dantes, and Sulastri, 2013)

In the application of cognitive-behavioral counseling, there are automatic thoughts in person, according Dharsana (2016: 98) automatic thoughts is part of an internal monologue individuals and can be shaped imaginations (image / shadow) words or both. Pikran-automatic thoughts very quickly and usually takes place at the end of consciousness. Automatic thoughts precede emotions, feelings, and occurs repeatedly even though we try to block it. Automatic thoughts can be associated with thoughts more complex underlying our thoughts are more real. Finally, automatic thoughts affect facial expressions, tone of voice and gestures. Based on these explanations persuasive to increase the interest of students, need to apply this cognitive-behavioral counseling, by emphasizing the automatic thoughts of students, so that students can be more realistic / real.

\section{Modeling Techniques Pan Balang Greed}

According Dharsana (2016) modeling technique is a way to introduce and counselors provide persuasive model that has a high interest to be able to do that, students were asked to replicate the model that has been provided by the counselor In line with this definition, Komalasari, et al. (2014: 176) argues modeling technique is the means used by counselors to raise interest persuasive through characterization, characterization is such characterizations through the film, a character's imagination (imaginary), and so forth. Modeling also called mimesis (imitation), which indicates that the observed behavior of other people, imitated, more an imitation of what is seen and observed(Adiputra, 2015; Ardana, Dharsana, \& Suranata, 2014; Damayanti \& Aeni, 2016; Mandala, Dantes, and Setuti, 2013; Sutanti, 2015) The process of learning through observation indicated that a learning process after observing the behavior of other people.

To increase students' interest persuasive researchers used modeling techniques symbolic model of Pan balang greedy. Mechanical modeling is not just imitating or repeating what do the models (others), but 
modeling involves the addition or subtraction of the observed behavior, menggenalisir various observations sekalligus, involves the cognitive processes (Alwisol, 2009).

According to Bandura (in Alwisol, 2009). Modeling the form of symbolic usually obtained from a model or a television movie that presents examples of behavior that can affect the viewer.

Tekink Pan balang greedy modeling is a way to increase students' interest persuasive manner Pan balang greedy portrayed as someone who has an interest in high persuasive. The purpose of the modeling technique Pan balang this greed is to make students capable of mimicking the role of the Pan balang greedy character has particularly high interest persuasive (Dharsana, 2016).

\section{Lesson Study}

Researchers also implement the model Lesson study in this research. (Yoshida, 1999 in Lewis, 2002) lesson study is a process that teachers or counseling teacher progressively striving to improve service delivery methods kenseling, by means of air-cooperation with the other teachers. While Ali (Sukirman 2006) looked at the lesson study as a model educator professional guidance through the learning assessment / counseling collaborative service delivery and sustainable(Cerbin \& Kopp, 2006; Fernandez, 2002; C. Lewis, 2000; CC Lewis, Perry, \& Hurd, 2009; C. Lewis, Perry, and Murata, 2006; Perry \& Lewis, 2009)

Based on the background of the above problems, operationally the issues to be investigated can be formulated problems of the "Is there any influence of cognitive-behavioral counseling by modeling techniques Pan balang greedy to increased interest persuasive students through lesson study in class VIII.4, SMP Negeri 2 Singaraja? "

In line with the formulation of the problems mentioned above, the purpose of this study was to determine the effect of cognitive behavioral counseling by modeling techniques Pan balang greedy to increased interest persuasive students through lesson study VIII.4 grade students of SMP Negeri 2 Singaraja.

\section{Method}

This type of research used in this research is the study design "quasi-experimental (Quasi Experiment)" Design nonequivalent pretest-posttest control group design. In sampling, a technique used random sampling and random class as an intact group. As is the random sampling means that sample population members is done by selecting a random sample, regardless of the strata that exist in the population. All things considered sector in the class have the same chance to be sampled (Dantes, 2012).

(Aronson \& Costanzo, 1988; Campion and McClelland, 1991; Hui, Lam, \& Law, 2000; Marvin, 1990; Taylor, Tracy, Renard, Harrison, \& Carroll, 1995)This study took a sample of students who demonstrate high interest criterion persuasive medium and low total of 37 students.

To collect data on interest persuasive students and to obtain accurate data in this study using multiple data collection techniques along with each device data collection, namely: (1) Questionnaire, (2) Methods of Observation, (3) Interview Method, (4) Diary.

Based on the validity of the tests conducted on the 30 items on the questionnaire self-achievement, moving rhitung coefficient of 0.310 to 0.747 . After consultation with rtabel on $\mathrm{df}=93$ with level siginifikansi $5 \%$ that is 0.202 indicates rhitung > rtabel so are not found items that fall, this means that the entire item is valid, and therefore the number of items the questionnaire self-achievement is a total of 30 items.

Ralpha comparison test reliability with $\mathrm{r}$ tabel show ralpha is 0.927 while rtabel ie $\mathrm{df}=95-2=93$ with a level of $5 \%$ ie 0.202 siginifikansi thus showing, ralpha> rtabel $0.927>0.202$, it can be concluded that the grains used instruments or degree of reliability Highly reliable Guilford high-based classification, so that the achievement of self intstrumen questionnaire is feasible for use in research.

Based on the test results of normality and homogeneity persuasive interest data above, it can be said that the requirements for testing the hypothesis with $\mathrm{t}$-test can be met. Therefore, hypothesis testing can be continued by using techniques Paired Sample Test. 
The results of t-test such as shows, $t$ value of 3,516 sig.0,01 with 0:01 $<0.05$. Thus, the null hypothesis (H0) stating that there is no influence cognitive-behavioral counseling by modeling techniques Pan balang greedy to increased interest persuasive students through lesson study VIII.4 grade students of SMP Negeri 2 Singaraja, rejected.

\section{Results and Discussion}

Empirical findings in this study stated that there are significant cognitive-behavioral counseling by modeling techniques Pan balang greedy to increased interest persuasive students through lesson study VIII.4 grade students of SMP Negeri 2 Singaraja. This result is evidenced by the results of t-test showed $t$ value of 3,516 sig.0,00 with 0:01 $<0.05$. with a significance level (p) $<0.05$, it can be concluded that the null hypothesis that "there is no influence cognitive-behavioral counseling by modeling techniques Pan balang greedy to increased interest persuasive students through lesson study in Class VIII.4SMP Negeri 2 Singaraja" rejected. This indicates that counseling services will be more effective if counselees in the implementation of the service is facilitated by modeling techniques Balang Greed Pan models.

Table 1. Average interest persuasive statistics

Paired Samples Statistics

\begin{tabular}{lccccr}
\hline & & mean & N & Std. deviation & Std. error Mean \\
\hline $\begin{array}{l}\text { interests } \\
\text { persuasive }\end{array}$ & pretest & 106.43 & 37 & 9842 & 1618 \\
\cline { 2 - 6 } & postes & 113.14 & 37 & 8159 & 1,341 \\
\hline
\end{tabular}

In applying cognitive-behavioral counseling by modeling techniques Balang Greedy Pan models, counselors are required to plan and carry out the process in accordance with the procedures and steps in the counseling techniques. Counselors are also required to be creative to provide new innovations in implementing guidance and counseling services in order to make counselees interested in following the process so that problems experienced service can be expressed openly and obtain appropriate troubleshooting with counselees needs.

\begin{tabular}{|c|c|c|c|c|c|c|c|c|c|}
\hline & & \multicolumn{5}{|c|}{ paired Differences } & \multirow[t]{3}{*}{$\mathrm{t}$} & \multirow[t]{3}{*}{$\mathrm{df}$} & \multirow{3}{*}{$\begin{array}{l}\text { Sig. (2- } \\
\text { tailed) }\end{array}$} \\
\hline & & \multirow[t]{2}{*}{ mean } & \multirow[t]{2}{*}{$\begin{array}{c}\text { Std. } \\
\text { deviation }\end{array}$} & \multirow[t]{2}{*}{$\begin{array}{l}\text { Std. } \\
\text { error } \\
\text { Mean }\end{array}$} & \multicolumn{2}{|c|}{$\begin{array}{l}95 \% \text { Confidence } \\
\text { Interval of the } \\
\text { Difference }\end{array}$} & & & \\
\hline & & & & & Lower & Upper & & & \\
\hline interests & pretest - & -6703 & 11597 & 1,907 & -10 & -2836 & - & 36 & .001 \\
\hline persuasive & posttest & & & & 569 & & 3516 & & \\
\hline
\end{tabular}

Table 2. Summary of Test Paired Sample Test 


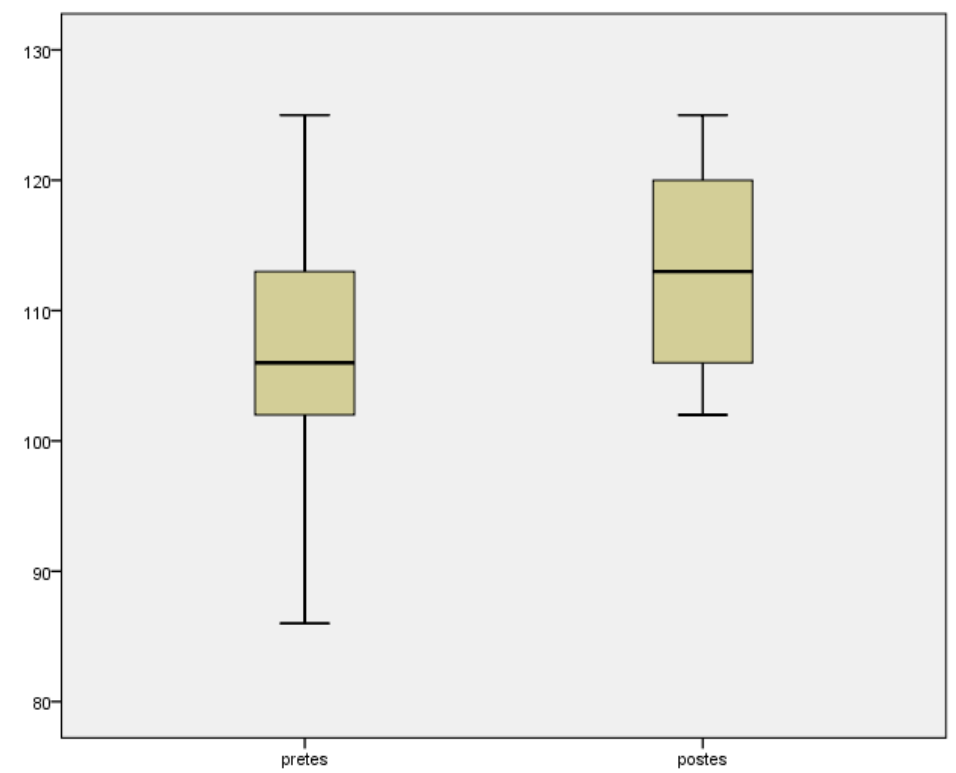

Figure 1. Plot the data pretest and post test

The implications for BK teacher or counselor is in providing counseling services should be better planned and systematic counseling in accordance with the procedures and steps involved in counseling techniques. In addition, counselors must be more active in seeking information and add knowledge about new things to enrich themselves with counseling techniques are more varied and can be applied in guidance and counseling services in schools. Counselors as a guidance counselor at the school should be able to facilitate and steer counselees in accordance with their potential and help reveal and help solve problems in the fields counselees personal, learning, social or career. With the right technique and according to the characteristics counselees problems, then the process of counseling services will run effectively and efficiently

The results of this study indicate that interest persuasive VIII.4 grade students of SMP Negeri 2 Singaraja that cognitive-behavioral counseling models modeling techniques Greed Pan Balang more increased from the students who were in the control group. Based on this statement we can say that the cognitive-behavioral counseling models modeling techniques Greed Pan right Balang applied in schools. The application of cognitive-behavioral counseling Pan models modeling techniques Balang Greed implications for the planning and development of guidance and counseling services model in terms of techniques and procedures of service activities provided to the counselee.

From the analysis of the study, the results of which diperolehlah found that counseling services will be more effective if counselees in pelaksananaan counseling services facilitated by cognitive behavioral modeling techniques Balang Greed Pan models. This result is evidenced by the results of t-test showed $t$ value of 3,516 sig.0,01 with 0:01 $<0.05$. with a significance level (p) $<0.05$, it can be concluded that the null hypothesis that "there is no influence cognitive-behavioral counseling by modeling techniques Pan balang greedy to increased interest persuasive students through lesson study in Class VIII.4SMP Negeri 2 Singaraja" rejected. Instead the alternative hypothesis (H1) who stated that "there are effects of cognitivebehavioral counseling by modeling techniques Pan balang greedy to increased interest persuasive students through lesson study in Class VIII.4SMP Negeri 2 Singaraja", is accepted.

\section{Conclusion}

Based on the analysis and discussion of the research results, it can be concluded that there are effects of cognitive-behavioral counseling by modeling techniques Pan balang greedy to increased interest persuasive students through lesson study VIII.4 grade students of SMP Negeri 2 Singaraja. To that end, the counseling teachers (counselors) should use counseling cognitive modeling techniques Balang Greed Pan models as an alternative in providing counseling services to the counselee (students). 


\section{References}

Dantes, Nyoman. (2012). Metode Penelitian. Yogyakarta : CV Andi Offset.

Chulsum, Umi and Windy Nova. (2006). Indonesian Dictionary. Surabaya: Yoshiko Press.

Corey, Gerald. (1988). Theory and Practice of Counseling and Psychotherapy. Jakarta: PT ERESCO.

Dantes, Nyoman. (2012). Methods. Yogyakarta: ANDI.

Dantes, Nyoman. (2012). Education Statistics. Singaraja: Graduate Undiksha.

Dantes, Nyoman. (2014). Analysis and Design of Experiments. Singaraja: Graduate Undiksha.

Darmayasa. (2013). Bhagavad-Gita (Song of the Lord): Yayasan Dharma Sthapanam

Department of Education and Culture. (2005). Indonesian dictionary. Jakarta: Balai Pustaka.

Dharsana, Ketut. (2010). Fundamentals of BK Series 2. Singaraja: Guidance and Counseling Department of Education Science faculty Undiksha.

Dharsana, Ketut. (2010). Theories of Counseling. Singaraja: Guidance and Counseling Department of Education Science faculty Undiksha.

Dharsana, Ketut. (2013). Cross-Cultural Counseling. Singaraja: Guidance and Counseling Department of Education Science faculty Undiksha.

Dharsana, Ketut. (2013). Practical Career BK. Singaraja: Guidance and Counseling Department of Education Science faculty Undiksha.

Dharsana, Ketut. (2014). Fundamentals of Counseling. Singaraja: Guidance and Counseling Department of Education Science faculty Undiksha.

Dharsana, Ketut. (2014). Models Theory, Techniques, Skill Counseling. Singaraja: Guidance and Counseling Department of the Faculty of Education University of Education Ganesha.

Dharsana, Ketut. (2014). Model Theory And Techniques For Writing Thesis. DPS.

Dharsana, Ketut. (2013). Personal Development counselor. Singaraja: Guidance and Counseling Department of Education Science faculty Undiksha.

Mahmudi, Ali. Developing Teacher Competence Through Lesson Study. Yogyakarta State University

Komalasari, Gantina, Wahyudi, Eka. (2014). Theory and Techniques Counseling. PT INDEKSS, Jakarta

Koyan, I Wayan. Education Statistics (2012). Quantitative Data Analysis Techniques. Singaraja: Ganesha Education University Press

Palmer, Stephen. (2011). Counseling and Psychotherapy. Yogyakarta: Student Library.

Mahmudi, Ali. Developing Teacher Competence Through Lesson Study. Yogyakarta State University

Adiputra, S. (2015). Against the Use of Mechanical Modeling Career Planning Students. FOCUS COUNSELING: Journal of Guidance and Counseling, 1 (1). Retrieved from http://ejournal.stkipmpringsewu-lpg.ac.id/index.php/fokus/article/view/70

Ajzen, I. (1971). Attitudinal vs. normative messages: An investigation of the differential effects of persuasive communications on behavior. Sociometry, 34 (2), 263-280. https://doi.org/10.2307/2786416

Ardana, INS, Dharsana, IK, \& Suranata, K. (2014). Application of Career Counseling Holland With 
Modeling Techniques To Improve Career Maturity Class X TKJ 1 Smk Negeri 3 Singaraja. Scientific Journal of Guidance and Counseling, 2 (1). Retrieved from http://ejournal.undiksha.ac.id/index.php/JJBK/article/view/3924

Armasari, KDWI, Dantes, ND, \& Sulastri, MS (2013). Application of Behavioral Counseling Model. Scientific Journal of Guidance and Counseling, 1 (1). Retrieved from http://ejournal.undiksha.ac.id/index.php/JJBK/article/view/900

Aronson, E., \& Costanzo, MA (1988). Using Social Cognition and Persuasion to Promote Energy Conservation: A Quasi-Experiment ', 1049-1066. Retrieved from https://pdfs.semanticscholar.org/dbfc/da46c7eb50307b070d2d711766622d4f7030.pdf

Campion, MA, \& McClelland, CL (1991). Interdisciplinary Examination of the Costs and Benefits of Enlarged Jobs: A Job Design Quasi-Experiment, 76 (2), 186-198. Retrieved from https://pdfs.semanticscholar.org/dbfc/da46c7eb50307b070d2d711766622d4f7030.pdf

Cerbin, W., \& Kopp, B. (2006). Lesson Study as a Model for Building Pedagogical Knowledge and Improving Teaching, 18 (3), 250-257. Retrieved from https://files.eric.ed.gov/fulltext/EJ1068058.pdf

D'Hondt, E., \& VSNU, V. van U. (2006). De universiteit, een vitaal organism: uitgave een van het ter gelegenheid afscheid van Ed d'Hondt als voorzitter van de Vereniging van Universiteiten VSNU. Vereniging van Universiteiten VSNU.

Damayanti, R., \& Aeni, T. (2016). The effectiveness of behavioral counseling by modeling techniques to cope with aggressive behavior in class viii learners b smp country 07 city Lampung. Counselees: Journal of Guidance and Counseling (E-Journal), 3 (1), 1-10. Retrieved from http://ejournal.radenintan.ac.id/index.php/konseli/article/view/572

Dharsana, K. (2017). Interests RPBK Series 1 (interests 1). Singaraja: BK FIP UNDKSHA.

Fernandez, C. (2002). Learning from Japanese Approaches to Professional Development. Journal of Teacher Education, 53 (5), 393-405. https://doi.org/10.1177/002248702237394

Greenwald, AG (1968). Cognitive learning, cognitive response to persuasion, and attitude change. Psychological Foundations of Attitudes. https://doi.org/10.1080/096020100389174

Hui, C., Lam, SSK, \& Law, PSC (2000). Instrumental Values of Organizational Citizenship Behavior for Promotion: A Quasi-Experiment Field. Journal of Applied Psychology, 85 (5), 822-828. https://doi.org/10.1037//0021-9010.85.5.822

Lewis, C. (2000). Lesson Study: The Core of Japanese Professional Development. Annual Meeting of the American Educational Research Association, 48. Retrieved from https://files.eric.ed.gov/fulltext/ED444972.pdf

Lewis, CC, Perry, RR, and Hurd, J. (2009). Improving mathematics instruction through lesson study: A theoretical models and North American case. Journal of Mathematics Teacher Education, 12 (4), 285-304. https://doi.org/10.1007/s10857-009-9102-7

Lewis, C., Perry, R., \& Murata, A. (2006). How Should Research Contribute to Instructional Improvement? The Case of Less. Retrieved from https://www.researchgate.net/profile/Catherine_Lewis5/publication/242574847_How_Should_Res 
earch_Contribute_to_Instructional_Improvement_The_Case_of_Lesson_Study/links/53fd156d0cf23 64ccc08a0fb.pdf

Mandala, SRIJ, Dantes, ND, \& Setuti, NIM (2013). Application of Behavioral Counseling With Modeling Techniques To Improve Emotional Intelligence Students In Class Xap1 Smk Negeri 1 Seririt Bulelengpenerapan District Counseling Behavioral Modeling Technique To Improve Emotional Intelligence. Scientific Journal of Guidance and Counseling, 1 (1). Retrieved from http://ejournal.undiksha.ac.id/index.php/JJBK/article/view/910

Marvin, E. (1990). A Quasi-Experiment Assessing the Effectiveness of TV Advertising Directed to Children. Retrieved from https://brainmass.com/file/1388319/quasi+experiment.pdf

Moyer-Guse, E. (2008). Toward a theory of entertainment persuasion: Explaining the persuasive effects of entertainment-education messages. School of Communication The Ohio State University, 18 (3), 407-425. https://doi.org/10.1111/j.1468-2885.2008.00328.x

Olson, JM, \& Zanna, MP (1993). Attitudes and Attitude Change. Annual Review of Psychology, 44 (1), 117-154. https://doi.org/10.1146/annurev.ps.44.020193.001001

Padmi, NMD (2017). Influence of Cognitive Behavioral Counseling Model Aaron Beck. Imiah Journal of $\begin{array}{lllll}\text { Education and } & \text { Learning, } & \text { Retrieved } & \text { from }\end{array}$ https://ejournal.undiksha.ac.id/index.php/JIPP/article/view/11974

Perry, RR, \& Lewis, CC (2009). What is successful adaptation of lesson study in the US? Journal of Educational Change, 10 (4), 365-391. https://doi.org/10.1007/s10833-008-9069-7

Rabiatul, BBAM (2017). Counseling With Cognitive Behavioral Therapy. UIN Sunan Ampel Surabaya. Retrieved from http://digilib.uinsby.ac.id/id/eprint/15269

Rokhimah, S. (2011). STUDY ON INTEREST IN CONTINUING STUDY CLASS VI MI GUPPI TALAGENING Bobotsari PURBALINGGA LESSONS YEAR 2009/2010. IAIN Purwokerto. Retrieved from http://repository.iainpurwokerto.ac.id/390/1/Cover_Bab I_Bab V_Daftar Pustaka.pdf

Sanyata, S. (2012). Theory and application behavioristic approach in counseling. Paradigm Journal, (14), 1-11. Retrieved from http://staff.uny.ac.id/sites/default/files/penelitian/Sigit Sanyata, M.Pd./B.1c.Artikel Scientific-Theory and Applications Behavioristik in Konseling.pdf

Saraswati, Kary, Dantes, ND, \& Sulastri, MS (2013). Application of Behavioral Counseling. Scientific Journal of Guidance and Counseling, 1 (1). Retrieved from http://ejournal.undiksha.ac.id/index.php/JJBK/article/view/769

Simorangkir, NR, Waiting, A. Aziz, A., Study, P., Psychology, M., MSc, P., ... Medan, UN (2014). CONTRIBUTION TO THE TEACHER persuasive communication. State University of Medan, 6 (2), 67-68.

Sinaga, FI (2014). EFFECT OF CONFIDENCE IN THE INTERESTS OF BRAND SWITCHING ENDOSER TOOTH PASTE PRODUCT (Study explanatif Confidence In Ad Endoser Testimonials Sensodyne Fresh Mint Brand Against Interest Sensitive Toothpaste Products Switching on Students. Journal of Scientific Communication Studies, 1-9. Retrieved from http: // ejournal.uajy.ac.id/id/eprint/5755 
Sutanti, T. (2015). Effectiveness Modeling Techniques To Improve Student Empathy Prodi Bk Ahmad Dahlan University. Journal of Educational Psychology and Counseling: Study Journal of Educational Psychology and Counseling, 1 (2), 188-198. Retrieved from http://ojs.unm.ac.id/index.php/JPPK/article/view/1906

Taylor, MS, Tracy, KB, Renard, MK, Harrison, JK, \& Carroll, SJ (1995). Due Process in Performance Appraisal: A Quasi-experiment in Procedural Justice. Retrieved from http://www.critical1911.com/documents/calnena2012/Taylor-Tracy-Renard-etc-1995.pdf

Wood, W. (2000). Attitude Change: Persuasion and Social Influence. Annual Review of Psychology, 51 (1), 539-570. https://doi.org/10.1146/annurev.psych.51.1.539

The authors declare that they have no significant competing financial, professional or personal interests that might have influenced the performance or presentation of the work described in this manuscript.

Copyrights Holder: Komang Adi Cipta Ananda, I Ketut Dharsana, Ni Ketut Suarni 2017

https://doi.org/10.23887/128162017

Open Access Article | CC-BY Creative Commons Attribution 4.0 International License. Word Count:
First Publication Right: BISMA The Journal of Counseling

\section{@creative}

